\title{
Contributions of Thermotolerant Bacteria to Organic Matter Degradation under a Hyperthermophilic Pretreatment Process during Chicken Manure Composting
}

Yun Cao, ${ }^{\mathrm{a}, \mathrm{b}, \mathrm{c}}$ Lin Wang, ${ }^{\mathrm{a}, \mathrm{d}}$ Yuting Qian, ${ }^{\mathrm{a}}$ Yueding Xu, ${ }^{\mathrm{a}, \mathrm{b}, \mathrm{c}}$ Huashan $\mathrm{Wu},{ }^{\mathrm{a}, \mathrm{b}, \mathrm{c}}$ Jing Zhang, ${ }^{\mathrm{a}, \mathrm{b}, \mathrm{c}}$ Hongying Huang, a,b,c,* and Zhizhou Chang a,b,c

\begin{abstract}
Composting technology comprising hyperthermophilic pretreatment (at $\geqslant$ $85^{\circ} \mathrm{C}$ for 2 to $4 \mathrm{~h}$, HTPRT) and aerobic composting was adopted to accelerate organic matter transformation and enhance nitrogen retention in chicken manure composting. The differences in physio-chemical parameters, successions, and metabolism functions of the bacterial community between HTPRT $\left(85^{\circ} \mathrm{C}, 4 \mathrm{~h}\right)$ and conventional composting (CK) were compared. The HTPRT composting system reached maturity 18 days in advance of CK. The HTPRT piles showed a lower maximum $\mathrm{N}$ loss $(27.1 \%$ vs. $39.0 \%)$. The bacterial structure in the HTPRT system differed remarkably from that in CK. Ureibacillus $(22.7 \%)$ and Ammoniibacillus (14.1\%) were the most predominant species in the thermophilic phase of HTPRT pile, while the curing phase was dominated by Thermobifida (12.8\%) and Saccharomonospora (11.8\%). The authors' results suggest that HTPRT improved the physical properties of the feedstock by reducing the bulk density, which favored microbiological activity, and thus improving composting efficiency.
\end{abstract}

Keywords: Hyperthermophilic pretreatment; Animal manure waste; Nitrogen retention; Thermotolerant bacteria; Microbial community

Contact information: a: Circular Agriculture Research Center, Jiangsu Academy of Agricultural Sciences, Nanjing 210014, P.R. China; b: Key Laboratory of Crop and Livestock Integrated Farming, Ministry of Agriculture, Nanjing 210014, P.R. China; c: Jiangsu Collaborative Innovation Center for Solid Organic Waste Resource Utilization, Nanjing 210014, P.R. China; $d$ : Nanjing Institute of Agricultural Sciences in Jiangsu Hilly Area, Nanjing 210046, P.R. China;

* Corresponding author: youngtsao66@126.com

\section{INTRODUCTION}

With the increase in the intensive livestock production, the quantity of poultry waste has dramatically increased in recent years (China Statistical Yearbook 2016; Zhang et al. 2016a). Composting is regarded as an effective technology for converting organic wastes, such as poultry manures, into usable organic fertilizers or a soil amendment. However, in some cases, the physio-chemical characteristics of organic wastes may make the wastes unsuitable for conventional composting. These properties may result in a lower temperature during composting and cause insufficient decomposition and poor sanitation of the composts. Moreover, the composting process can involve a considerable generation of malodourous gases such as ammonia $\left(\mathrm{NH}_{3}\right)$, hydrogen sulfide, and volatile organic compounds (Jurado et al. 2015). It is estimated that ammonia emissions contributed to $71 \%$ to $88 \%$ of nitrogen loss in composting facilities (Steiner et al. 2010). 
Composting is a self-heating aerobic process driven by the actions of microbial communities (Gannes et al. 2013a). These communities are affected by the types of substrates present and environmental conditions, such as temperature, ventilation conditions, and $\mathrm{pH}$ (Tortosa et al. 2017). The process of composting is generally comprised of three predictable phases, mesophilic, thermophilic, and curing (Gannes et al. 2013a; Zhang and Sun 2014). These temperature phases reflect the activities of successive microbial populations responsible for the degradation of organic matter. As a result, temperature is regarded as one of the crucial variables during transformation of organic matter $(\mathrm{OM})$. To promote the efficient $\mathrm{OM}$ degradation, the composting process is expected to continuously remain in the thermophilic phase. Thus, various countermeasures have been used to increase the temperatures during the composting of animal manures: aeration control, bulk agent amendment (Jurado et al. 2015; Zhou et al. 2015; Zhao et al. 2017; Liu et al. 2019), and direct microbial inoculation (Zhao et al. 2017; 2018). In fact, compost conditions, such as the $\mathrm{pH}, \mathrm{C} / \mathrm{N}$ ratio, and oxygen concentration improvement, have significant influence on the growth of microbial communities (Zhang and Sun 2014; Tortosa et al. 2017).

Recently, composting of organic wastes by using a hyperthermophilic pretreatment (HTPRT) process has been developed by Yamada et al. (2007) to solve malodorous odor problems related to ammonia emission during the composting process. During the process, feedstocks first were subjected to a HTPRT reactor followed by a conventional composting system. The temperature of the raw materials in the HTPRT reactor reached $100{ }^{\circ} \mathrm{C}$, and the maximum temperature was kept for at least $30 \mathrm{~min}$. The HTPRT has been reported as a novel technology that has prominent features, such as high bioconversion efficiency, accelerated formation of humic acids, low ammonia emission, and accelerated removal of antibiotic resistance genes and mobile genetic elements during composting (Liao et al. 2018).

Although there have been some reports concerning composting combined with an HTPRT process, the mechanism by which the HTPRT process stabilizes animal manures in the subsequent aerobic composting system remains to be further researched. Previous studies mainly have focused on the dynamic changes in the composition of the microbial communities responsible for $\mathrm{OM}$ conversion during different composting phases. Few studies have concerned the metabolic activity and functional diversity of the bacterial community, which are of great importance to reveal OM transformation in composting.

The objectives of the study were to: 1) compare the difference in the succession and metabolism function of bacterial community between the HTPRT and conventional composting; 2) evaluate the effect of the HTPRT on organic $\mathrm{C}$ degradation during poultry manure composting; and 3) identify the relationship between the environmental factors, including temperature, moisture, ash, total organic carbon (TOC), total nitrogen (TN), ammonium $\left(\mathrm{NH}_{4}{ }^{+}-\mathrm{N}\right)$, and nitrate $\left(\mathrm{NO}_{3}{ }^{-} \mathrm{N}\right)$ contents, and bacterial composition in the HTPRT composting process.

\section{EXPERIMENTAL}

\section{Materials and HTPRT Process}

The raw materials of chicken manure and rice straw were obtained from Luhe Animal Experimental Base of Jiangsu Academy of Agricultural Sciences (Jiangsu, China). The rice straw was cut into small pieces ranging from $2 \mathrm{~cm}$ to $4 \mathrm{~cm}$. The chemical 
parameters of the feedstocks before and after HTPRT are shown in Table 1. In order to match what is being done in a composting facility, the HTPRT process and the subsequent thermophilic composting process were conducted in separated systems. Details of the HTPRT process have previously been described in Cao et al. (2018). Briefly, in the HTPRT reactor (400 L, Fig. 1A), about $250 \mathrm{~kg}$ of the mixed chicken manure and rice straw were stirred using a blender inside the reactor. The mixed materials were heated by dimethyl silicone oil circulating until the preset HTPRT condition $\left(85^{\circ} \mathrm{C}\right)$ was reached and sustained for $4 \mathrm{~h}$. Compulsory ventilation was set at the rate of $100 \mathrm{~L} / \mathrm{kg} \mathrm{TS} \cdot \mathrm{h} \mathrm{L}^{-1}$ with a blower. After the temperature of the mixed material declined to ambient temperature, it was transferred to a vessel for the subsequent composting (Fig. 1B).

Table 1. Properties of Raw Materials for Composting

\begin{tabular}{|c|c|c|c|c|}
\hline Materials & Moisture (\%) & $\begin{array}{c}\text { Total Organic } \\
\text { Carbon }(\mathrm{g} / \mathrm{kg})\end{array}$ & $\begin{array}{c}\text { Total Nitrogen } \\
(\mathrm{g} / \mathrm{kg})\end{array}$ & $\mathrm{C} / \mathrm{N}$ \\
\hline Chicken manure & 71.2 & 288 & 25.62 & 11.24 \\
\hline Rice straw & 9.5 & 405 & 6.12 & 66.17 \\
\hline
\end{tabular}

A

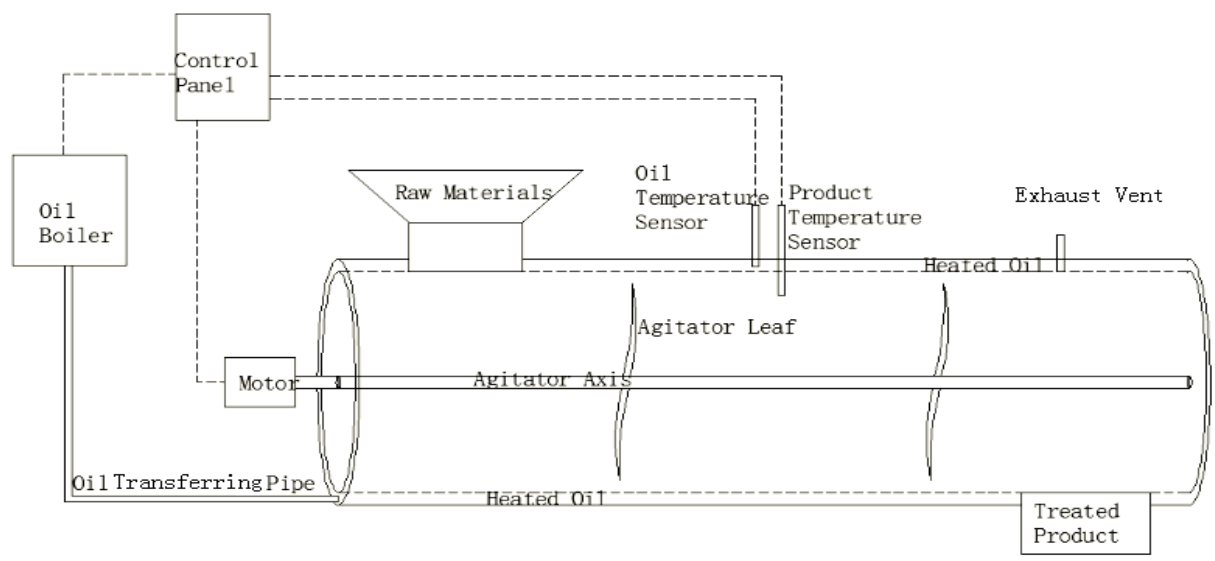

B

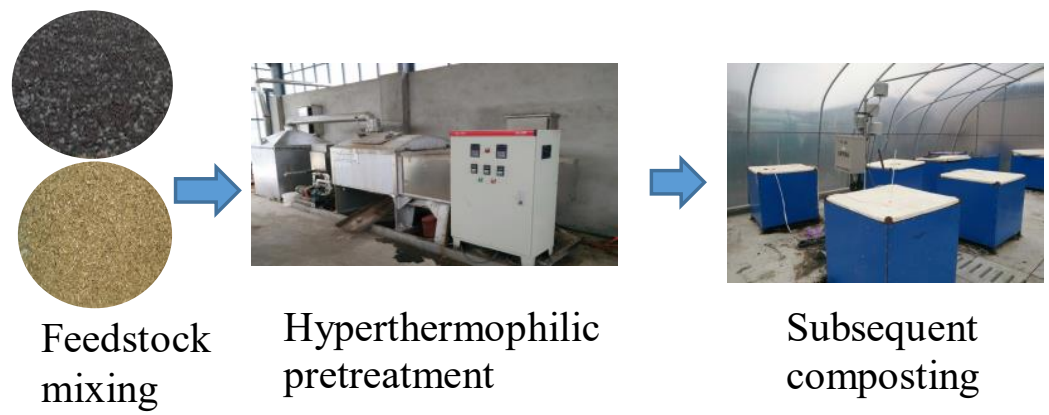

Fig. 1. Schematic diagram of the HTPRT reactor $(A)$ and the HTPRT composting process (B)

\section{Composting setup}

The chicken manure and rice straw residues, with or without HTPRT, were adjusted to the same moisture content $(62 \%)$, and then they were spread on separate plastic sheets and moved into stainless cubic bins $(65 \mathrm{~cm} \times 65 \mathrm{~cm} \times 65 \mathrm{~cm})$ with a volume of $300 \mathrm{~L}$ for the subsequent aerobic in-vessel composting. The bins were externally insulated with two layers of foam ( $5 \mathrm{~cm}$ in thickness) and aluminum foil thermal insulators to minimize the convective heat loss. A removable foam lid was put on the top of each reactor to facilitate intermittent mixing and sampling of the substrate during composting. A foam board was 
fixed on the inner side at the bottom. The uniformly distributed holes $(2 \mathrm{~cm}$ in diameter) were cut both at the top and the bottom of the bin. The area of the holes accounted for approximately $1 / 4$ of the total area of the foam board. Three thermocouples connected to a data logger were fitted at $15 \mathrm{~cm}, 30 \mathrm{~cm}$, and $45 \mathrm{~cm}$ from the bottom of each bin to record the temperature of the composts at the interval of $60 \mathrm{~min}$. A metal grid with $1 \times 1 \mathrm{~mm}^{2}$ holes was fixed to sustain the composting materials and to allow aeration from the bottom. Fresh air was naturally supplied without forced aeration by turning the composting material manually at 1 -week intervals throughout the 62-day-long composting process. While the substrate was being loaded into each bin, original samples were withdrawn (bottom, middle, and top) immediately for subsequent analyses, and the composting time was noted as day zero (Day 0).

\section{Sample collection}

A total of 7 solid samples (approximately $250 \mathrm{~g}$ ) were taken from each bin throughout the composting process at days $0,7,14,21,28,42$, and 62 . Three subsamples taken from the top, middle, and bottom of the reactor were collected and thoroughly mixed. After homogenization, each sample was divided into two parts, with one part kept fresh at $4{ }^{\circ} \mathrm{C}$, and another part air-dried and ground to pass through a $0.25-\mathrm{mm}$ sieve. The air-dried and ground samples were used to analyze the total organic carbon (TOC), total nitrogen (TN), moisture, and ash contents. The fresh samples were used to analyze the $\mathrm{pH}$, ammonium nitrogen $\left(\mathrm{NH}_{4}{ }^{+}-\mathrm{N}\right)$, nitrate nitrogen $\left(\mathrm{NO}_{3}{ }^{-} \mathrm{N}\right)$, germination index, and DNA extraction.

\section{Methods}

Physio-chemical analysis

The bulk density of the compost was detected using a $100 \mathrm{~cm}^{3}$ container. The container was filled with samples, and then the samples were slightly compacted to ensure absence of large void spaces. The mass of the compost and container was weighed, and the bulk density was calculated by dividing the weight of the material by the volume of the container (Jain et al. 2019). The moisture content was assessed via oven-drying at $105^{\circ} \mathrm{C}$ for $24 \mathrm{~h}$, and the oven-dried sample was combusted at $550{ }^{\circ} \mathrm{C}$ for $6 \mathrm{~h}$ in a muffle furnace (ash). The TOC was measured by oxidation with potassium dichromate and TN using the Kjeldahl method on an Automatic Kjeldahl System (Hanon K1100; Hanon Instrument, Jinan, China). The $\mathrm{pH}$ was measured in aqueous suspensions of the fresh compost samples (1:5, w/v, compost:water ratio) using a $\mathrm{pH}$ electrode (Mettler Toledo, Columbus, $\mathrm{OH}$, USA). The concentrations of $\mathrm{NH}_{4}{ }^{+}-\mathrm{N}$ and $\mathrm{NO}_{3}{ }^{-} \mathrm{N}$ were measured by an Auto Analyzer (AA3; Bran and Luebbe, Werkstraße, Germany). Phytotoxicity to the Chinese cabbage by a Germination Index (GI) test was completed according to the protocol proposed by Zucconi et al. (1981).

\section{Microbiological analysis - Enumeration of aerobic microorganisms}

Specific culture media and incubation conditions were employed for the enumeration of major microbial groups in the $\mathrm{CK}$ and HTPRT piles throughout composting. Fresh samples $(10 \mathrm{~g})$ were suspended in $90 \mathrm{~mL}$ of sterile water, shaken (170 $\mathrm{rpm}$ ) at room temperature for $30 \mathrm{~min}$, and standard ten-fold serial dilutions in sterile water were performed. Mesophilic and thermophilic bacteria, actinobacteria, and fungi were cultured in Nutrient Agar (Sigma-Aldrich, St. Louis, MO, USA), Gauze's Synthetic Medium No. 1 (Solarbio, Beijing, China), and Rose Bengal Agar (Sigma-Aldrich, St. 
Louis, MO, USA), respectively. The mesophilic microbiota and thermophilic microbiota were incubated at $30{ }^{\circ} \mathrm{C}$ or $55^{\circ} \mathrm{C}$ for 2 to 3 days (bacteria), 3 to 4 days (actinobacteria), and 4 to 7 days (fungi) (Liu et al. 2017).

\section{DNA extraction}

Before DNA extraction, the sample was thoroughly mixed and freeze-dried on a freeze dryer (Alpha 1-2 Ldplus; Martin Christ Gefriertrocknungsanlagen, Osterode am Harz, Germany). Then, the samples were ground with liquid nitrogen to avoid inhomogeneity. The microbial DNA of the samples was extracted using the FastDNA SPIN Kit for Soil (MP Biomedicals, Solon, OH, USA). Pellets (300 mg) from each sample were collected in triplicate according to the manufacturer's instructions. The DNA quality was assayed using the Nanodrop-2000 spectrophotometer (Thermo Fisher Scientific, Waltham, MA, USA).

\section{PCR amplification and sequencing}

The V3-V4 region (254 bp) of the 16S rRNA gene was amplified via PCR using the following primers:

- Forward: Nobar_341F (CCTACGGGNGGCWGCAG)

- Reverse: Nobar_805R (GACTACHVGGGTATCTAATCC)

The barcode was a 6-base sequence that was inserted between the adapter and the reverse primer so that different samples could be distinguished in just one sequencing run. The PCR reactions were conducted in a $50 \mu \mathrm{L}$ mixture containing $25 \mu \mathrm{L}$ premix (Ex Taq, Version 2.0, TaKaRa, Shiga, Japan), $50 \mathrm{ng}$ DNA templates, and $1 \mu \mathrm{L}(10 \mathrm{mM})$ forward and reverse primers. The mixtures were denatured at $95{ }^{\circ} \mathrm{C}$ for $5 \mathrm{~min}$, and they were then amplified in 35 cycles of $95{ }^{\circ} \mathrm{C}$ for $30 \mathrm{~s}, 55^{\circ} \mathrm{C}$ for $15 \mathrm{~s}$, and $72{ }^{\circ} \mathrm{C}$ for $30 \mathrm{~s}$, with a final extension at $72{ }^{\circ} \mathrm{C}$ for $10 \mathrm{~min}$. The band was extracted and purified using the QIA quick gel extraction kit (Qiagen, Hilden, Germany). After purification and quantification, an equal amount of PCR products from different samples were mixed, purified, and quantified. Combined PCR products were sent to Sangon Biotech Co., Ltd. (Shanghai, China) for Illumina sequencing.

\section{Post sequencing analysis}

After demultiplexing the raw FASTQ files, the reads generated from the paired-end sequencing using Mothur v. 1.30.1 software (The University of Michigan, Ann Arbor, MI, USA) were combined. Then, the primers, barcodes, and adaptors were trimmed off. Reads shorter than $200 \mathrm{bp}$ were discarded. The quality filtering was also performed using Mothur, discarding reads with ambiguous sequences. The UCHIME program was used to identify and remove chimeric sequences. The sequences that contained more than one ambiguous base or had homopolymers were filtered using USEARCH (version 5.2.236, Sangon Biotech, Shangha, China). Reads shorter than 200 bp were also discarded.

The remaining sequences ("clean sequences") were clustered into OTUs with 97\% similarity cut-off using USEARCH. The QIIME program (version 1.9.0, Sangon Biotech, Shanghai, China) was used to assign taxonomy to OTUs based on the Silva-compatible reference alignment (version 119, Sangon Biotech, Shangha, China) at a set confidence threshold of $80 \%$ to generate an OTU table. Canonical correspondence analysis (CCA) was performed to analyze the relationships between species diversity and physio-chemical parameters using the Canoco 4.5 software package (Microcomputer power, Ithaca, NY, USA). 
Statistical analyses

A one-way analysis of variance was conducted to test the differences in the physiochemical properties among different composting times. Losses of OM and TN were calculated from the initial $\left(A_{1}\right)$ and final $\left(A_{2}\right)$ ash contents, and the initial $\left(P_{1}\right)$ and final $\left(P_{2}\right)$ fraction concentrations according to the equation of Benito et al. (2003) (Eq. 1):

$$
\% \text { Loss }=100-\left[100 \times\left(A_{1} \times P_{2}\right) /\left(A_{2} \times P_{1}\right)\right]
$$

All statistical analyses employed the SPSS software (SPSS 19.0, IBM, Armonk, NY, USA). The data were processed using Microsoft Excel (Microsoft Corporation, 2007, Redmond, WA, USA) and all diagrams were plotted with Origin 9.0 (OriginLab Corporation, Northampton, MA, USA).

\section{RESULTS AND DISCUSSION}

\section{Effects of HTPRT on Composting Performance}

The temperature profiles of the two composting treatments were different (Fig. 2a). The HTPRT rapidly activated the composting process. The temperature of the HTPRT system rapidly increased to approximately $50^{\circ} \mathrm{C}$ after 8 days of composting and reached peak temperature at approximately $70{ }^{\circ} \mathrm{C}$ on day 10 , while in the $\mathrm{CK}$ the temperature rose at a much slower rate and reached $50{ }^{\circ} \mathrm{C}$ after 11 days of fermentation. This was consistent with previous studies using hyperthermophilic composting technology to process sewage sludge (Liao et al. 2018; Yu et al. 2018) and waste materials for local communities in Japan (Kanazawa et al. 2008). Liao et al. (2018) and Yu et al. (2018) registered $20{ }^{\circ} \mathrm{C}$ to $30{ }^{\circ} \mathrm{C}$ higher temperatures during the thermophilic stage than conventional composting because the HTPRT shaped a distinct microbial community that released the metabolic heat during bacterial fermentation.

The HTPRT also affected the physical properties of the composting mixture (Table 2). During the HTPRT, the color of the feedstocks changed from dark yellow to brown. The moisture content for the HTPRT product decreased from $62 \%$ to $57 \%$, due to the moisture loss during the pretreatment process. The large size clumps were broken into smaller particles due to the stirring of the feedstocks by the agitator, resulting in a decreased bulk density of the initial feedstocks, which suggested that HTPRT reduced the probability of the formation of anaerobic sites and facilitated $\mathrm{O}_{2}$ diffusion through the composting mixture (Sánchez-García et al. 2015).

Table 2. The Physical Characteristics of Composts from CK and HTPRT Systems

\begin{tabular}{|c|c|c|c|c|c|c|c|c|}
\hline & \multicolumn{2}{|c|}{$\begin{array}{c}\text { Moisture } \\
\text { Content (\%) }\end{array}$} & \multicolumn{2}{|c|}{$\begin{array}{l}\text { Bulk Density } \\
\left(\mathrm{g} / \mathrm{cm}^{3}\right)\end{array}$} & \multicolumn{2}{|c|}{$\mathrm{pH}$} & \multicolumn{2}{|c|}{$\begin{array}{l}\text { Ash } \\
(\%)\end{array}$} \\
\hline & CK & HTPRT & CK & HTPRT & CK & HTPRT & CK & HTPRT \\
\hline $\begin{array}{l}\text { Before } \\
\text { HTPRT }\end{array}$ & $57.6 a$ & $57.6 \mathrm{~b}$ & $0.27 \mathrm{~b}$ & $0.27 \mathrm{~b}$ & $8.13 b$ & $8.13 b$ & $41.19 b$ & $41.19 b$ \\
\hline After HTPRT & $57.6 a$ & $62.3 a$ & $0.27 \mathrm{~b}$ & $0.24 \mathrm{c}$ & $8.13 b$ & $6.86 c$ & $41.19 \mathrm{~b}$ & $38.85 \mathrm{c}$ \\
\hline $\begin{array}{c}\text { After In- } \\
\text { vessel } \\
\text { Composting }\end{array}$ & $22.2 b$ & $29.0 c$ & $0.36 a$ & $0.31 a$ & $8.67 a$ & $8.65 a$ & $56.57 a$ & $63.28 a$ \\
\hline
\end{tabular}



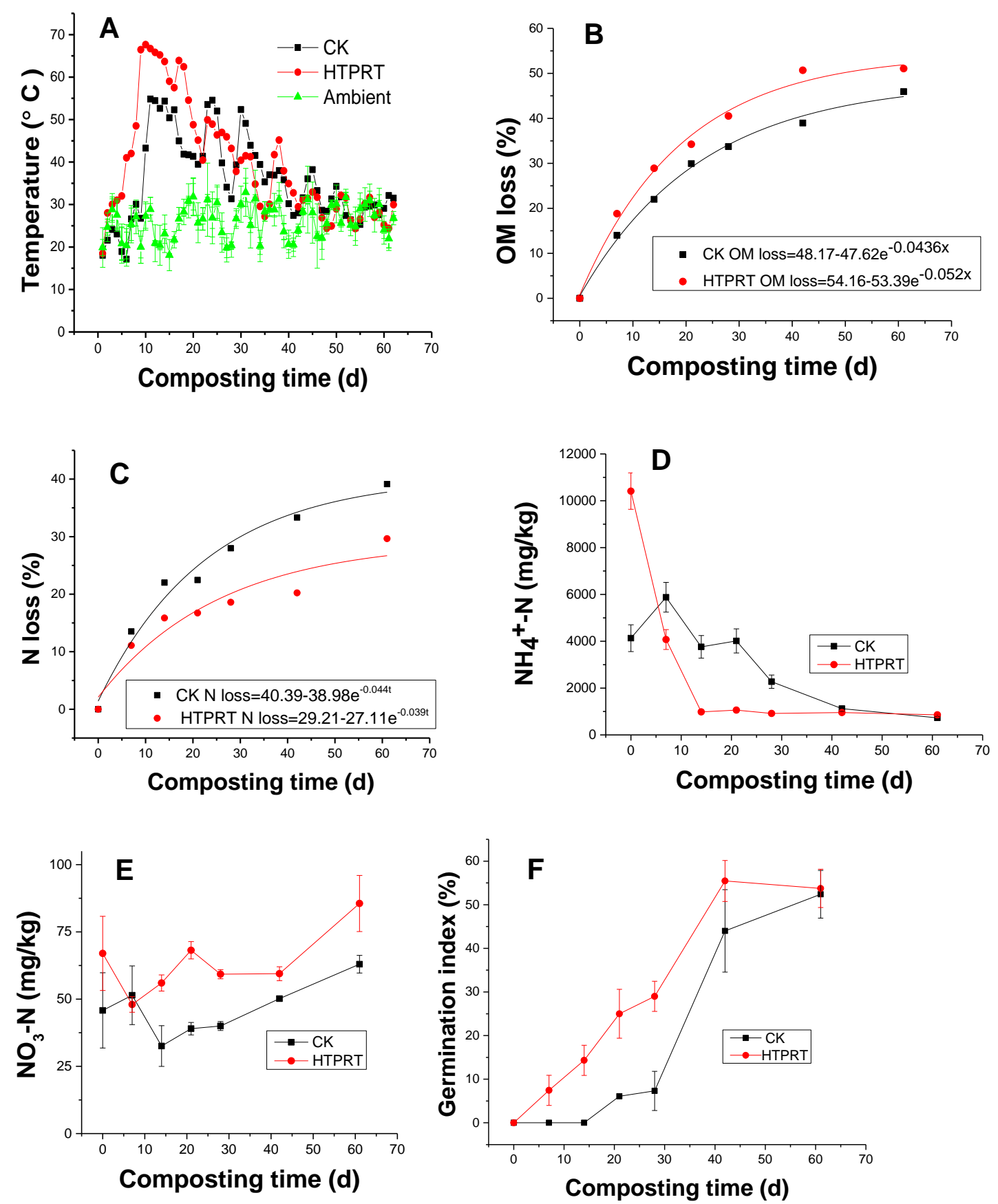

Fig. 2. Evolution of physio-chemical properties during aerobic composting of chicken manure and rice straw with or without HTRPT: a) Temperature; b) OM loss; c) $\mathrm{N}$ loss; d) $\mathrm{NH}_{4}{ }^{+}-\mathrm{N}$; e) $\mathrm{NO}_{3}{ }^{-}-\mathrm{N}$; and f) Germination index

The $\mathrm{pH}$ value of the compost with the HTPRT at the start of subsequent composting (Day 0) was approximately 2.2 units lower than the CK compost. This $\mathrm{pH}$ difference was attributed to the presence of organic acids formed normally during the HTPRT process of lignocellulosic residues (Nakhshiniev et al. 2014). Nevertheless, the $\mathrm{pH}$ in the compost from the two treatments turned from acidic to weakly alkaline. This could be explained both by decomposition of organic acids by microorganisms as well as by the release of ammonia from mineralization of organic nitrogen (Fan et al. 2017). 
The loss of organic matter due to degradation and volatilization or leaching will result in an increase proportion of ash, which does not break down during the composting process (Jindo et al. 2016). The initial ash content in the CK and HTPRT was observed as $41.2 \%$ and $38.8 \%$, respectively. The change in ash content followed an increasing trend and recorded values of $56.6 \%$ and $63.8 \%$ for the final composting products from CK and HTPRT (Table 2), respectively. The increased content of the ash in the final product of the HTPRT corresponded to the higher organic carbon mineralization during composting.

The HTPRT exerted a slight effect on the organic carbon degradation dynamics (Fig. 2b). The OM losses followed a first-order kinetic model, as generally found in composting experiments (Sánchez-García et al. 2015). The HTPRT piles showed a higher maximum OM loss (a: 54.2\% in HTPRT vs. $48.2 \%$ in CK) and higher rate constant (k: 0.052 day $^{-1}$ in HTPRT vs. 0.0436 day $^{-1}$ in CK) and mineralization rate $(\mathrm{a} \times \mathrm{k}: 2.8 \%$ in HTPRT vs. $2.1 \% \mathrm{OM}_{\text {day }^{-1}}$ in $\mathrm{CK}$ ). The reason behind the stimulation of the $\mathrm{OM}$ mineralization in the HTPRT piles might be related to the decreased bulk density as mentioned above.

Compared to OM loss, the HTPRT exerted more pronounced effects on TN loss during composting (Fig. 2c). The HTPRT piles showed a lower maximum N loss (a: $27.1 \%$ vs. $39.0 \%)$ and rate constant ( $\mathrm{k}: 0.039$ vs. 0.044 day $\left.^{-1}\right)$. The lower $\mathrm{N}$ loss caused by HTPRT suggested a more rapid degradation of organic matter and greater nitrogen retention (Liu et al. 2017). These results agreed with the previous studies that the hyperthermophilic composting decreased the total $\mathrm{N}$ loss during the composting of cattle manure (Yamada et al. 2007).

The evolution pattern of $\mathrm{NH}_{4}{ }^{+}$in the HTPRT piles differed from that in CK (Fig. $2 \mathrm{~d}$ ). In the $\mathrm{CK}$ system, there was an increase in the concentration of $\mathrm{NH}_{4}{ }^{+}$during the initial stage of the composting, reflecting rapid OM mineralization. However, in the HTPRT pile, the $\mathrm{NH}_{4}{ }^{+}$concentration showed a downward trend from the beginning of the composting process, and the peak concentration of $\mathrm{NH}_{4}{ }^{+}$appeared on day 1 . These results suggested an enhancement of the ammonification process associated to a high mineralization rate during the pretreatment process. Previous studies showed that the amino acid in the compost raw materials was increased by 10.6\% (Cao et al. 2019). This might be due to the breakdown of protein in the substrate in the hyperthermal pretreatment (Eskicioglu et al. 2017). In addition, the nitrification process was also promoted by HTPRT, such that a remarkably higher concentration of $\mathrm{NO}_{3}{ }^{-}$was recorded during the maturity stage of composting (Fig. 2e). This might have been due to the better aeration conditions given by HTPRT that enhanced the nitrification process driven by aerobic nitrifying bacteria (Zhang and Sun 2014).

The evolution of maturity as indicated by Germination indices (GI) during the composting process is presented in Fig. $2 \mathrm{f}$. The GI above $50 \%$ is defined as a quality parameter for composts produced from manures and slurries (Bernal et al. 1998). According to the value of the parameter, both piles achieved a suitable degree of maturity at the end of the composting process. In the first two weeks, the GI values in both piles were quite low (0\% in CK vs. $14.3 \%$ in HTPRT), which could have been due to the high concentrations of ammonium and organic acids (Liu et al. 2011). However, HTPRT-treated piles were stabilized and detoxified faster than the control piles. The GI increased to 55\% on day 42 and stayed around that value afterwards in the HTPRT piles, whereas the control piles needed an additional 18 days of composting to reach the same degree of maturity. 
Table 3. Aerobic Microbial Populations During Composting in Different Systems

\begin{tabular}{|c|c|c|c|c|c|c|c|c|c|c|}
\hline \multirow{3}{*}{$\begin{array}{l}\text { Composting } \\
\text { Time (d) }\end{array}$} & \multicolumn{2}{|c|}{ Mesophilic } & \multicolumn{2}{|c|}{ Mesophilic } & \multicolumn{2}{|c|}{ Mesophilic } & \multicolumn{2}{|c|}{ Thermophilic } & \multicolumn{2}{|c|}{ Thermophilic } \\
\hline & \multicolumn{2}{|c|}{ Bacteria $\left(\times 10^{9} \mathrm{CFU} / \mathrm{g}\right)$} & \multicolumn{2}{|c|}{ Fungi $\left(\times 10^{3} \mathrm{CFU} / \mathrm{g}\right)$} & \multicolumn{2}{|c|}{ Actinomycetes $\left(\times 10^{6} \mathrm{CFU} / \mathrm{g}\right.$} & \multicolumn{2}{|c|}{ Bacteria $\left(\times 10^{6} \mathrm{CFU} / \mathrm{g}\right)$} & \multicolumn{2}{|c|}{ Actinomycetes $\left(\times 10^{4} \mathrm{CFU} / \mathrm{g}\right)$} \\
\hline & CK & HTPRT & $\mathrm{CK}$ & HTPRT & $\mathrm{CK}$ & HTPRT & $\mathrm{CK}$ & HTPRT & $\mathrm{CK}$ & HTPRT \\
\hline 0 & $5.11 b$ & 1 & $5.21 a$ & 1 & $0.7 \mathrm{~b}$ & I & $0.22 c$ & 1 & $5.88 \mathrm{ab}$ & $3.78 c$ \\
\hline 7 & $7.81 b$ & $4.12 b$ & $3.22 a$ & $1.36 a$ & $2.72 a$ & $0.84 c$ & $5.71 a b$ & I & $4.33 b$ & $2.52 c$ \\
\hline 14 & $42.38 a$ & $3.19 \mathrm{~b}$ & $4.69 a$ & $0.18 \mathrm{~b}$ & $0.16 \mathrm{~b}$ & $0.34 c$ & $13.26 \mathrm{a}$ & $5.68 c$ & $10.58 \mathrm{a}$ & $72.28 a$ \\
\hline 21 & $4.64 b$ & $52.7 a$ & 1 & $2.03 a$ & $0.19 b$ & $4.06 \mathrm{ab}$ & $1.06 \mathrm{~b}$ & $129.49 a$ & $27.03 a$ & 51.73ab \\
\hline 28 & $15.6 a b$ & $20.49 a$ & I & 1 & $0.16 b$ & $2.4 \mathrm{~b}$ & $4.47 a b$ & $47.97 \mathrm{~b}$ & $5.17 \mathrm{ab}$ & $30.01 \mathrm{ab}$ \\
\hline 42 & $0.02 c$ & $2.89 b$ & 1 & 1 & $0.92 b$ & 6.73ab & $0.8 \mathrm{bc}$ & 54.51ab & $2.02 b$ & 32.02ab \\
\hline
\end{tabular}




\section{Impact of HTPRT on Evolution of Culturable Microorganisms}

The mesophilic microorganisms were undetectable and only thermophilic actinomycetes were detected in the feedstocks after HTPRT according to the plate counts (Table 3), suggesting that the number of OTUs from the 16S rDNA pyrosequencing analysis might be overestimated in the initial stage of subsequent composting. However, as the composting progressed, both the mesophilic and thermophilic microbiota were recovered in the HTPRT piles.

The thermophilic bacteria and actinobacteria reached the highest counts at the thermophilic stage. More specifically, thermophilic bacterial and actinobacterial counts were greater in the HTPRT than the control pile at the thermophilic and maturity stages, suggesting that several species of thermophilic bacteria were recovered at the thermophilic stages and were well adapted to the process conditions (Gannes et al. 2013b). Compared to prokaryotic microbiota, mesophilic fungi existed only at the early stage throughout the whole process, and no culturable thermophilic fungi were detected. This might be because very few thermophilic fungi are culturable by classical culture-based methods (LangaricaFuentes et al. 2014).

In general, there was no difference in the microbial evolution throughout composting to what has been reported elsewhere: more microorganisms were detected at the bio-oxidative phase, and a decrease in counts around the thermophilic phases occurred (Steger et al. 2007; Partanen et al. 2010; Xi et al. 2015). However, the extent to which microbial counts, particularly the thermophilic counts, decreased in the HTPRT piles at the maturity stages was much lower.

Once recovered from the HTPRT reactor, composting microbiota in the subsequent composting began to grow faster. These results suggested a growth stimulation of the composting thermophiles that explained the quick activation and maintenance of high temperature in the HTPRT piles (Fig. 2a). In fact, due to hydrothermal reaction, more easily degradable compounds could have been initially released and made available to microorganisms, which in turn would be able to grow and release metabolic heat to produce higher temperatures in the pile (Ding et al. 2017; Eskicioglu et al. 2017).

\section{Impact of HTPRT on Microbial Community}

The composition of bacterial 16S rRNA sequences was determined via high throughout sequencing. Firmicutes, Actinobacteria, Proteobacteria, and Bacteroidetes accounted for most of the sequences and were considered the dominant phyla (Fig. 3). It has been demonstrated that DNA can be degraded into smaller fragments during heat treatment (Rice and Doty 1957). Surprisingly in the present study, compared to CK0, the community structure of $\mathrm{HO}$ did not change remarkably (Fig. 3), indicating that the heating process did not damage the integrity of DNA in the composting materials. However, an earlier study showed that the bacterial community in the composting materials containing cow dung and sawdust differed much between the composting processes with and without HTPRT $\left(100{ }^{\circ} \mathrm{C}, 2 \mathrm{~h}\right)$ (Yamada et al. 2008). The difference between the two studies might be due to different temperature, duration, and size of the DNA fragment to be amplified (Musto et al. 2014).

The temperature in the heating process of this study was lower than the critical temperature value for DNA degradation, which is between $88^{\circ} \mathrm{C}$ to $100{ }^{\circ} \mathrm{C}$. The size of the DNA fragment was much smaller in this study, and smaller DNA fragments are easier to be amplified (Sakalar et al. 2012; Musto et al. 2014). 


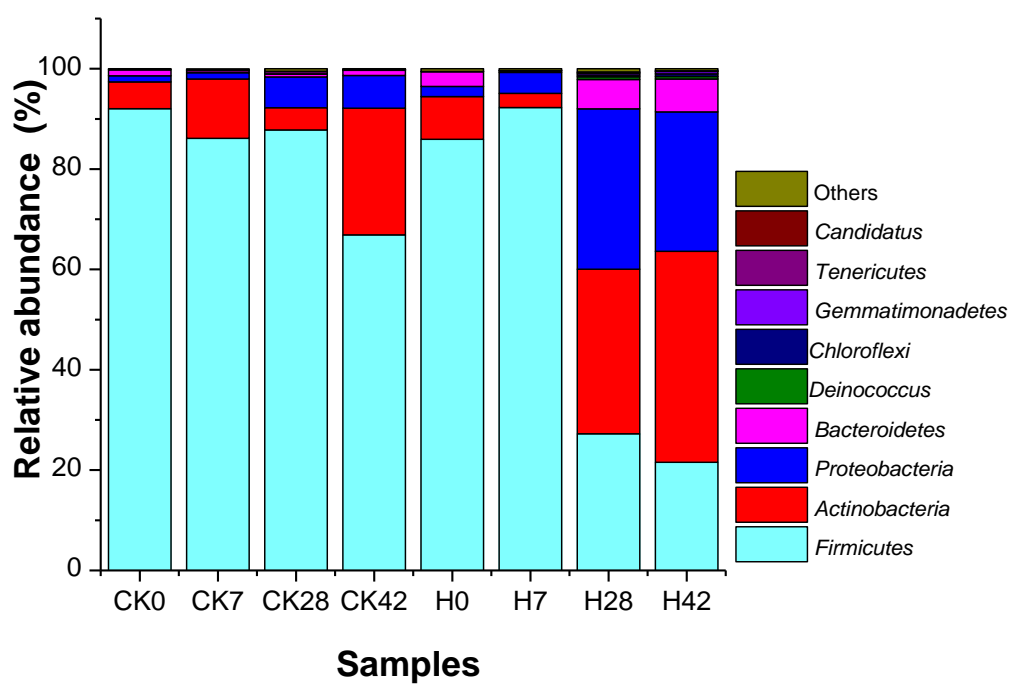

Fig. 3. Taxonomic classification at the phylum level of predominant 16S rRNA gene sequences (relative abundance at top 20) in compost samples during aerobic composting of chicken manure and rice straw with or without HTRPT. The labels CK0, CK7, CK28, CK42 represent samples collected at days $0,7,28$, and 42 from composts without HTPRT and $\mathrm{H} 0, \mathrm{H} 7, \mathrm{H} 28, \mathrm{H} 42$ represent samples collected at days $0,7,28$, and 42 from composts with HTPRT. The same labeling system is used in subsequent figures.

Species succession occurred over time in both composts. Firmicutes was the most abundant bacteria during the whole CK composting process (Fig. 3). In the initial stage (D0), Lactobacillus (CK 42\% vs. HTPRT 28\%) was the most abundant bacteria in both piles. As composting progressed, Ureibacillus (22.68\%, phylum Firmicutes) and Ammoniibacillus (14.08\%, phylum Firmicutes) were the predominant species in the thermophilic phase of the HTPRT pile, while the curing phase was dominated by Thermobifida (12.75\%, phylum Firmicutes), Saccharomonospora (11.81\%, phylum Actinobacteria), and Georgenia (8.9\%, phylum Actinobacteria). However, Bacillus was the predominant species during the thermophilic (26.30\%) and curing (28.56\%) stages of CK (Fig. 4). The authors' results revealed that the HTPRT increased the relative abundance of Actinobacteria but decreased the level of Firmicutes compared to the traditional composting (Fig. 3). These results were consistent with the bacterial community in hyperthermal compost derived from industrial waste materials in the literature, which state that the predominant species present are Saccharopolyspora (32.9\%) and Georgenia (15.7\%). To the authors' knowledge, these genera have not been reported to be predominant in any other composts obtained by traditional composting (Lv et al. 2015; Zhang et al. 2016a), and little is known of their functions and roles in the HTPRT composting process. Because Actinobacteria is considered an important lignocellulose degrader in composts (Ryckeboer et al. 2003; Steger et al. 2007), a higher abundance of Actinobacteria in HTPRT piles suggests that a bacterial community with a more stable structure could be developed in the later stage (Zhang et al. 2016b). Enhancing the populations of Actinobacteria could speed up the degradation of macromolecules, such as cellulose, hemicellulose, and lignin, thus improving the composting efficiency. However, Firmicutes (74\%) was predominant in sewage hyper-thermal compost samples (Tashiro et al. 2016). These results suggested that a distinct bacterial community structure was formed in the HTPRT process. Additionally, even with HTPRT, the predominant phyla were diverse and specific in composts with different raw materials (Tashiro et al. 2016). 


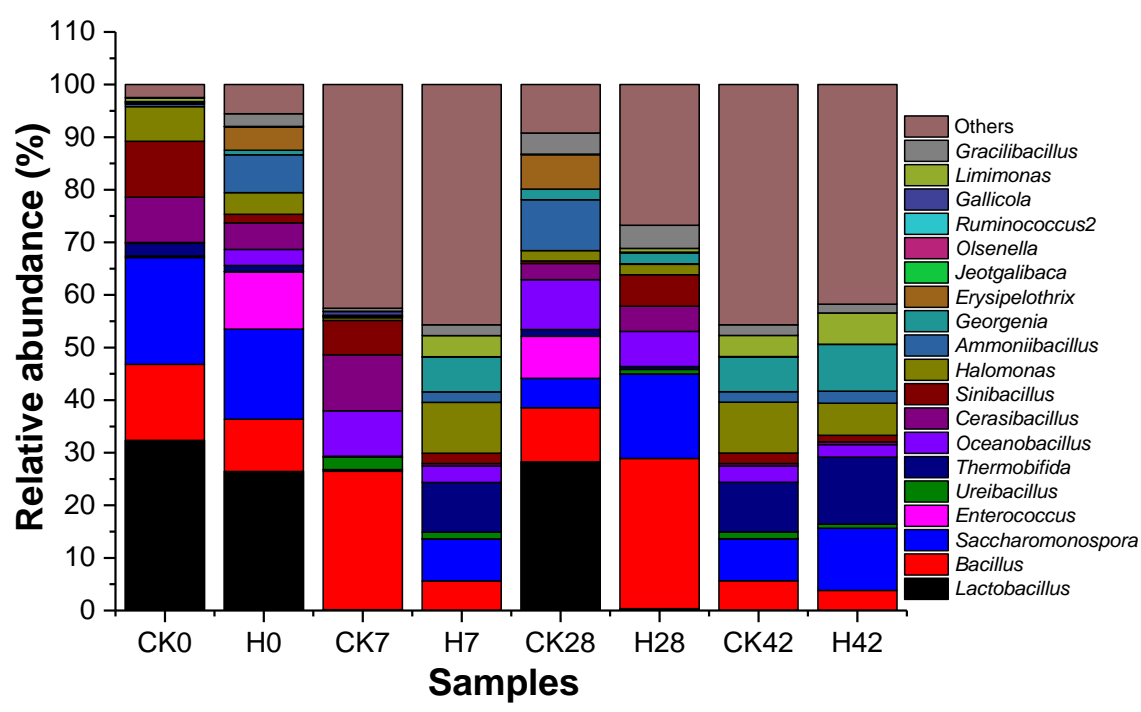

Fig. 4. Taxonomic classification at the genus level of predominant 16S rRNA gene sequences (relative abundance at top 20) in compost samples collected at days $0,7,28$, and 42 during aerobic composting of chicken manure and rice straw with or without HTRPT

\section{Bacterial Community and its Association with Physio-chemical Parameters}

The CCA was used to analyze the relationship between environmental parameters (temperature, TOC, $\mathrm{TN}, \mathrm{pH}, \mathrm{NH}_{4}{ }^{+}-\mathrm{N}$, or $\mathrm{NO}_{3}{ }^{-}-\mathrm{N}$ ) and bacterial community (Fig. 5a). The first two axes of the CCA explained $53.2 \%$ and $23.6 \%$ of the variation in the species data, respectively. As shown in Fig. 5a, the CCA plot grouped eight compost samples into four distinct clusters. Compost samples collected at day 0 (CK0, H0) and day 7 for the $\mathrm{CK}$ were separated from those collected at day 28 and day 42, suggesting that the bacterial community profiles in the raw materials and CK samples collected at the initiation stage were similar. As the composting progressed, samples collected from HPC on day 7 and from CK on day 28 were clustered together. The results suggested an important role of temperature for shaping the microbial structures in the CK and HTPRT piles, and the effect was more noticeable in HTPRT. Notably, H28 and H42 samples were clustered together, and they were separate from the samples of CK42, which suggested that composts in HTPRT became stable after 28 days of composting and reached maturity over 14 days in advance than that of CK. Similar results were reported by Yu et al. (2018), stating that sewage sludge from hyperthermophilic composting became mature after 24 days of composting, while composts collected on day 48 in traditional composting were still immature.

A specific CCA analysis was performed on the relationship between bacterial community and the above selected 6 environmental factors in the HTPRT (Fig. 5b). The first two CCA axes explained $51.8 \%$ and $23.1 \%$ of the variation in the species-environment relationship. In this plot, the 20 most abundant OTUs identified at the genus level were divided into three groups throughout the HTPRT composting. Group 1 was positively associated with TOC, $\mathrm{NH}_{4}{ }^{+}-\mathrm{N}$, and $\mathrm{NO}_{3}{ }^{-}-\mathrm{N}$, suggesting that the microbial community structure was likely to be affected by the mineralization rate of organic carbon and nitrogen, while remarkable relationships existed between the temperature and Group 2. Thermotolerant microorganisms are believed to play a major role in organic matter degradation in composts. Kanazawa et al. (2008) reported that the metabolic heat released from the bio-fermentation of organic wastes raises the processing temperature sufficiently 
high at $70{ }^{\circ} \mathrm{C}$ to $100{ }^{\circ} \mathrm{C}$ to support thermophilic bacteria in HTPRT, such as Ureibacillus and Ammoniibacillus, which belong to the order of Bacilli in the thermophilic stage of composting. However, when the temperature of the pile cooled down, the moderately thermophilic bacteria, such as Saccharomonospora and Thermobifida, which both belong to the order of Actinomycetales, became the predominant species. This could be further evidenced by the enhanced populations of these thermophilic microorganisms in the thermophilic and cooling stages of the HTPRT pile. Group 3 was related to TN and $\mathrm{NH}_{4}{ }^{+}-$ $\mathrm{N}$, suggesting their roles in the organic $\mathrm{N}$ formation during the humification process. This suggested that Group 3 indicated the maturity of HTPRT. Early studies reported the reappearance of Saccharomonospora in the maturation stage, suggesting this group of microorganisms may be a potential indicator of compost maturity (Steger et al. 2007). In addition, due to the high salt contents in animal manures, an enhanced population of halotolerant Halomonas and Gracilibacillus may have also contributed to the shortened length of animal waste composting (Tang et al. 2011).

Notably, the authors previously isolated extreme thermophiles growing at $>80{ }^{\circ} \mathrm{C}$ in the hyper-thermal composting process, such as Rhodothermus sp. CGMCC 7.246 and Thermus CGMCC 7.247. However, these extreme thermophiles were not dominant in the compost as revealed by Illumina pyrosequencing in the present study, while the Thermus was predicted to be the dominant genus responsible for the hyperthermophilic composting of sewage sludge (Yu et al. 2018). The difference in the dominant species may be mainly be due to the different composting techniques applied. In their study, a period of 9 days for the hyperthermophilic phase $\left(>80^{\circ} \mathrm{C}\right)$ was recorded, while only $4 \mathrm{~h}$ of hyperthermophilic pretreatment of the raw materials was applied in the present study.
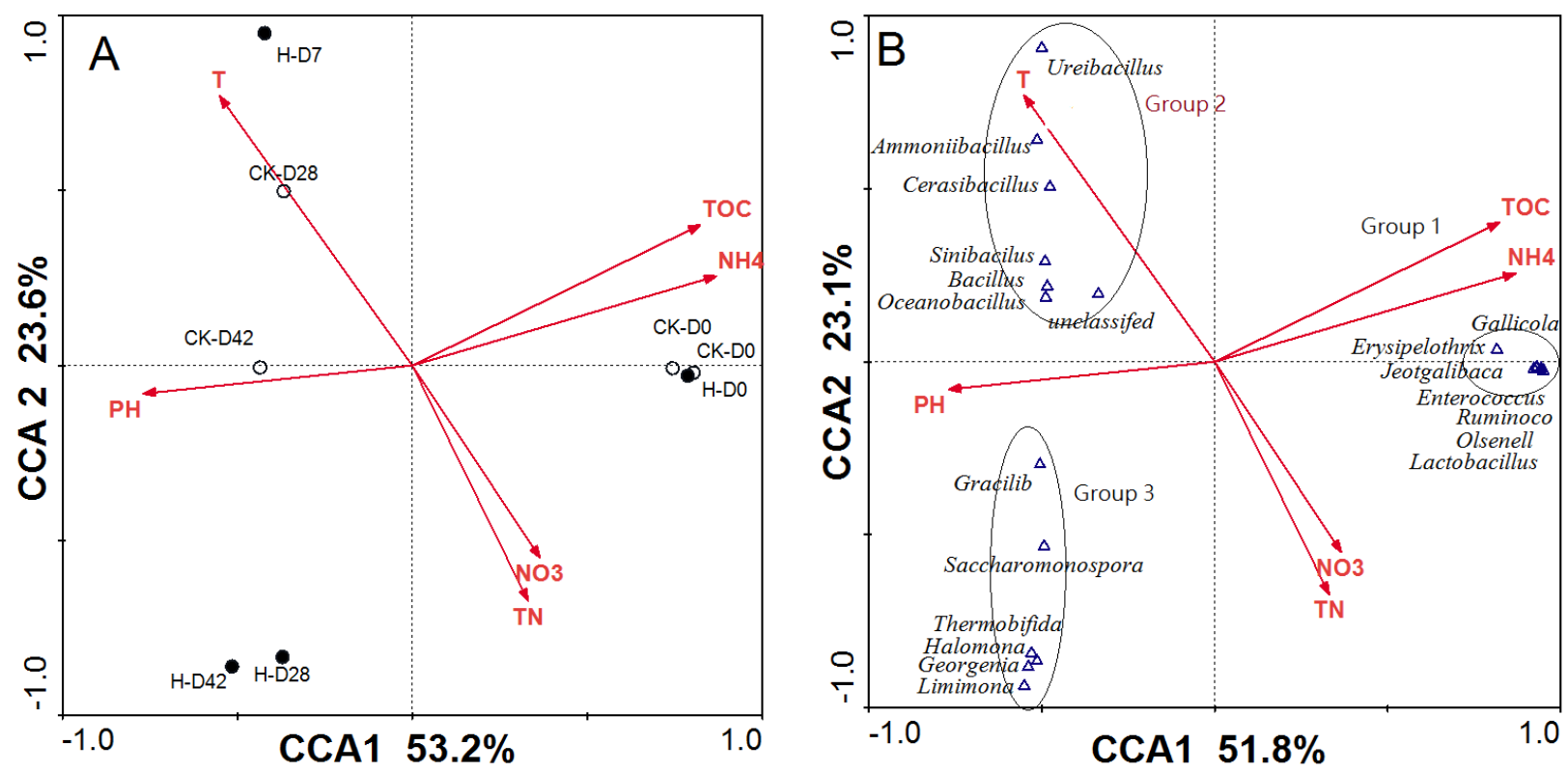

Fig. 5. (a) Canonical correspondence analysis (CCA) between microbial community and physiochemical parameters for aerobic composting of chicken manure and rice straw with or without HTRPT; (b) CCA of the correlation between microbial community and physio-chemical parameters for HTPRT piles 


\section{Bacterial Function Prediction}

PICRUSt is a highly regarded bioinformatics tool that allows prediction of functional profiles based on phylogenetic composition of communities using databases KEGG and COG (Samaddar et al. 2019). The bacterial metabolic properties during composting in the two piles were predicted using PICRUSt based on 16s rRNA homology and conserved feature of functional contribution (Fig. 6). There were four functional groups of the genes, including metabolism (Fig. 6A, 6B) (51.6\% to $57.6 \%$ ), environmental information processing (Fig. $6 \mathrm{E}, 6 \mathrm{~F})(15.6 \%$ to $22.5 \%$ ), genetic information processing (Fig. $6 \mathrm{G}, 6 \mathrm{H})(15.6 \%$ to $22.5 \%)(16.1 \%$ to $25.7 \%)$, and cellular processes (Fig. 6C, 6D) (4.9\% to $9.7 \%$ ) (Fig. 6).

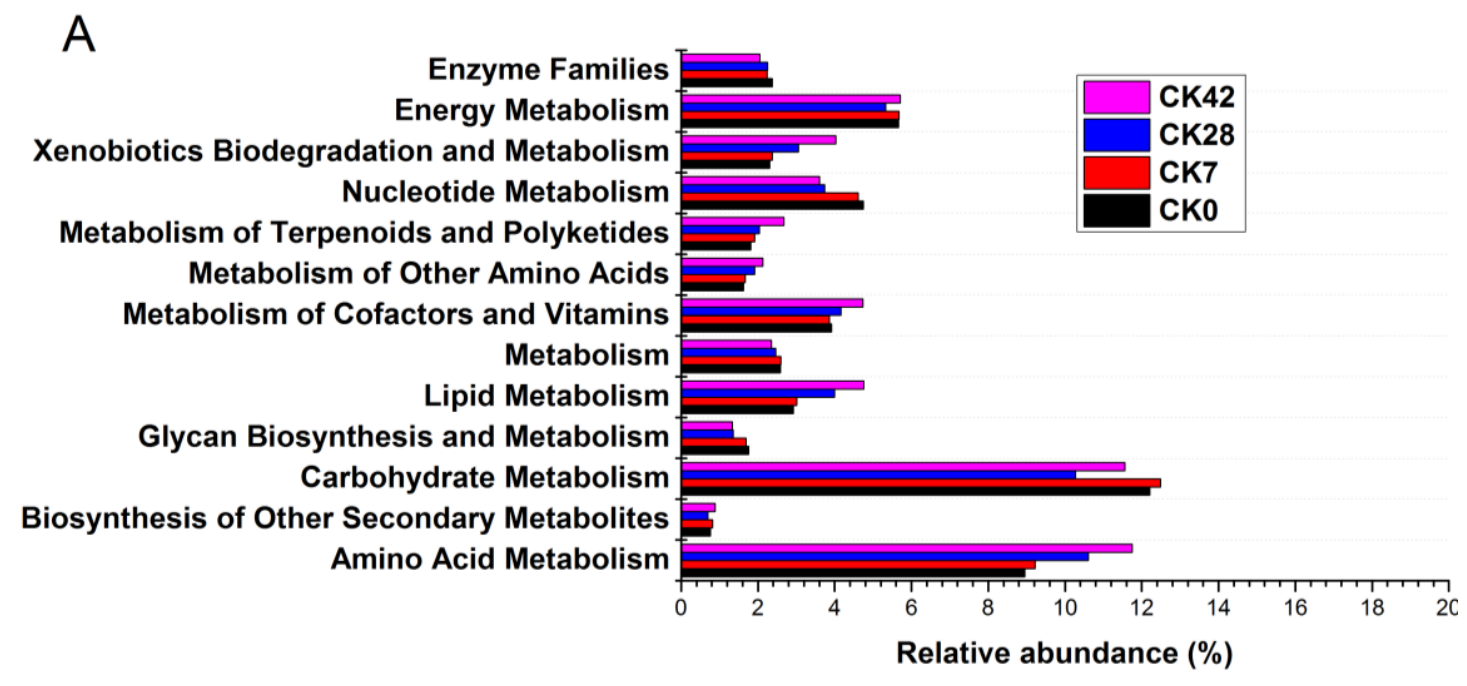

B

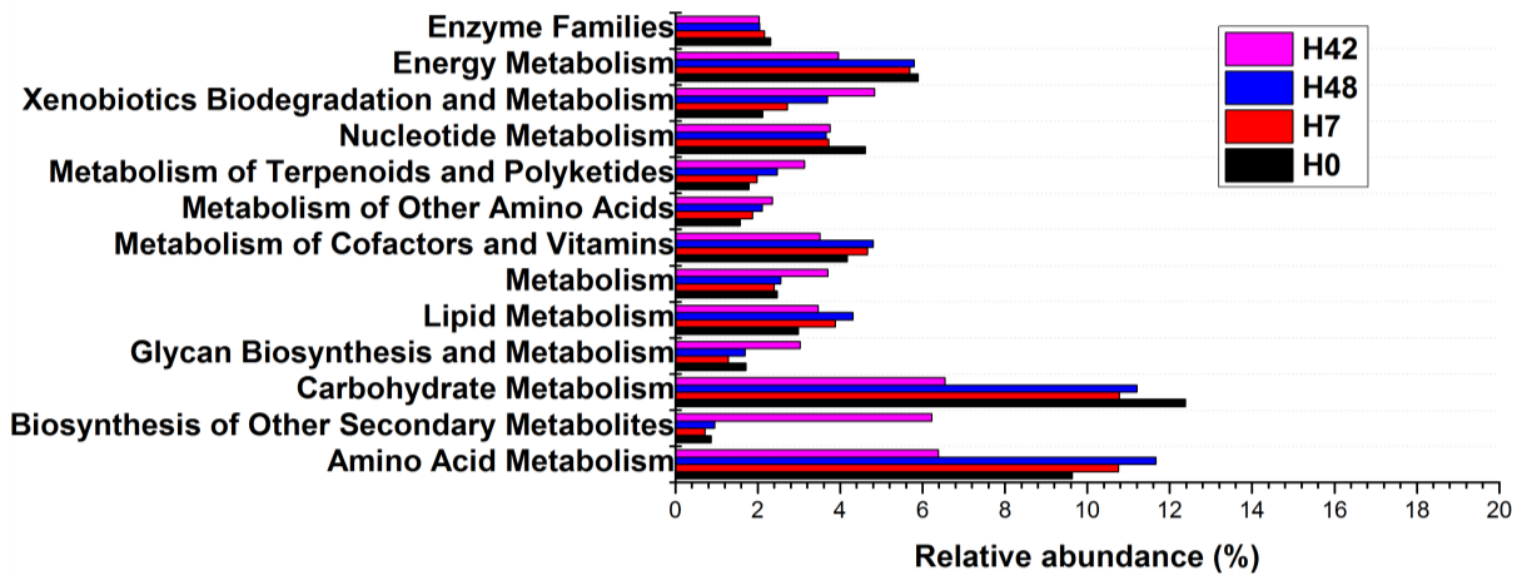

C

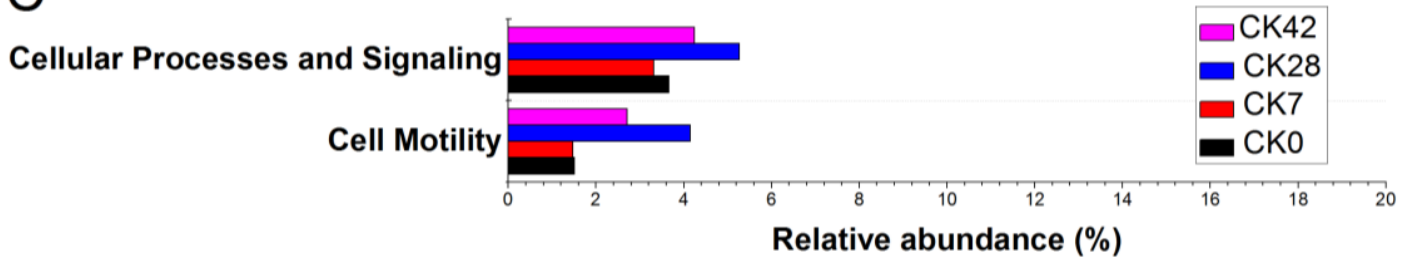

Cao et al. (2019). "Bacteria degradation: composting," BioResources 14(3), 6747-6766. 6760 

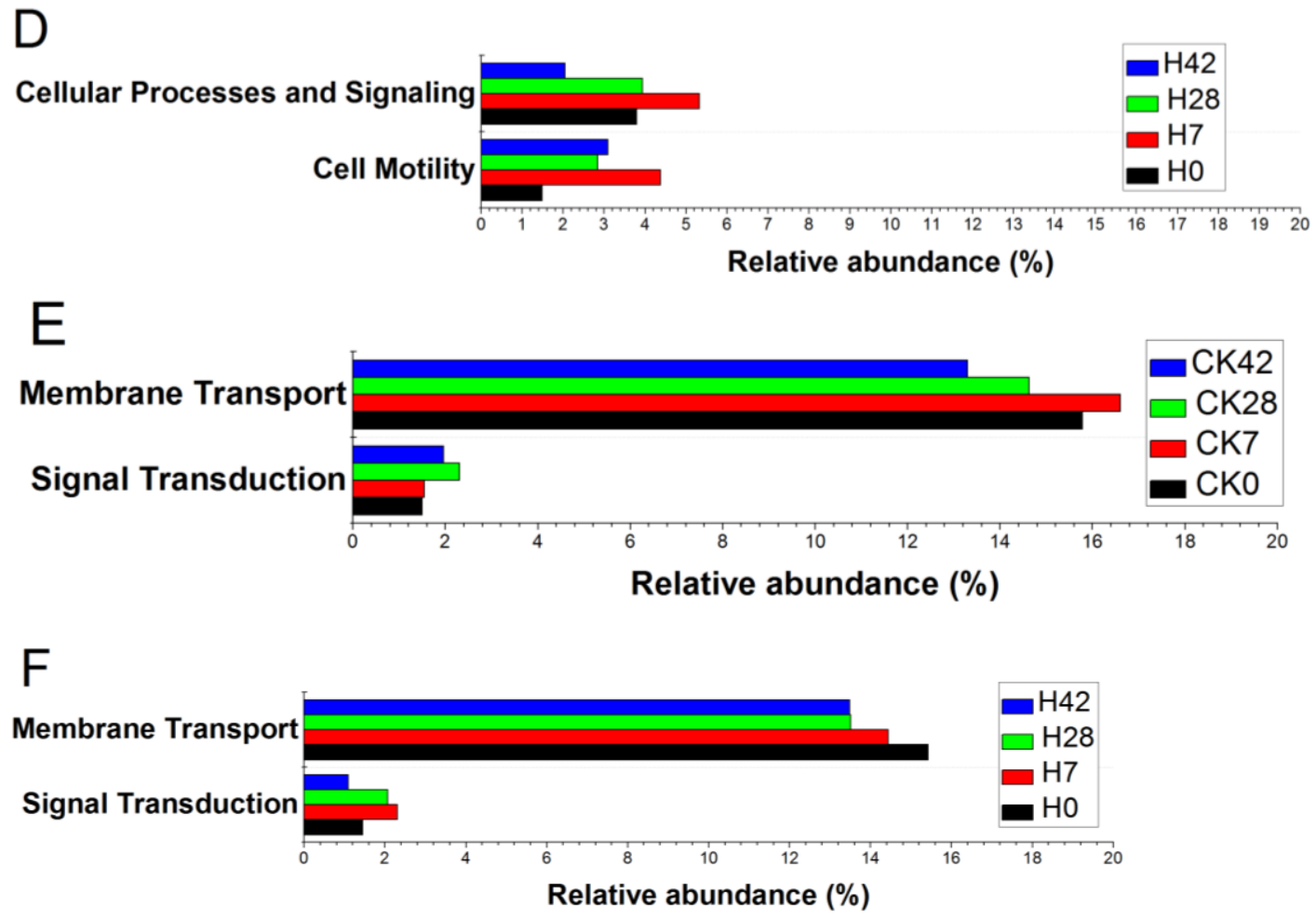

G

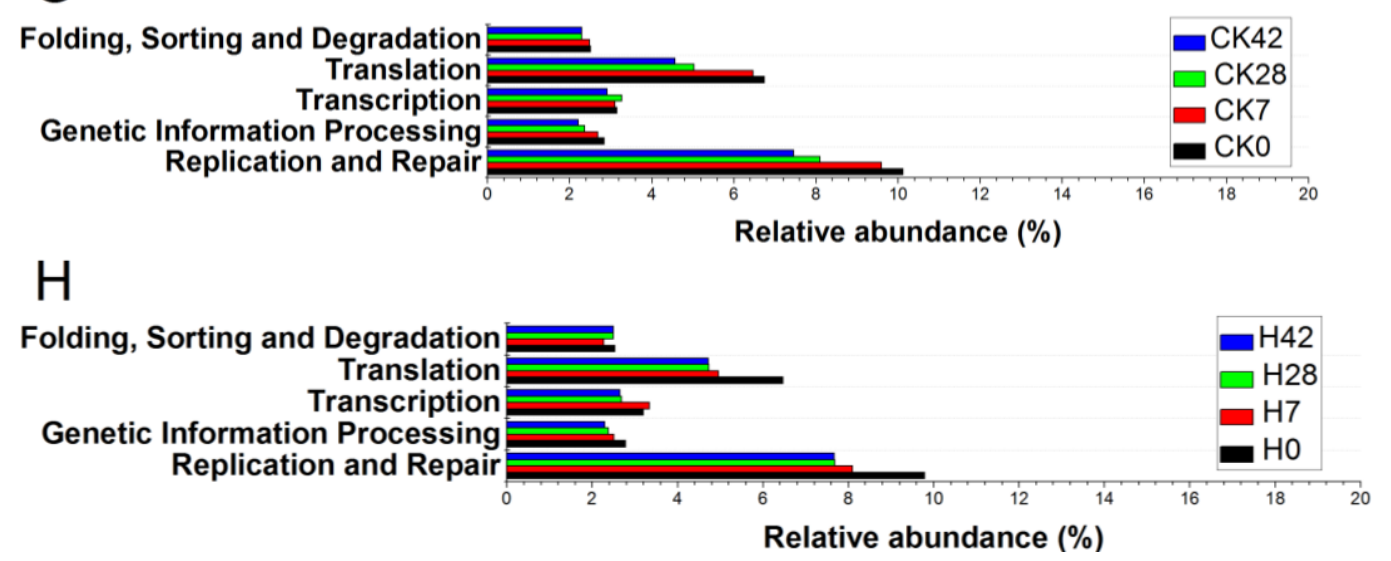

Fig. 6. PICRUSt function prediction based on KEGG database

The most frequently occurring type in the metabolism category was carbohydrate metabolism (6.5\% to $12.3 \%$ ), followed by amino acid metabolism (6.4\% to $11.7 \%)$, energy metabolism (3.9\% to 5.9\%), and nucleotide metabolism (3.6\% to $4.7 \%)$. Bacterial members originating from composts pretreated with HTPRT were characterized by higher abundance of genes encoding enzymes related to amino acid metabolism, carbohydrate metabolism, and lipid metabolism compared to composts without HTPRT in the initial and thermophilic stages of composting (day 0 and day 7). These results are in line with the previous observations where common enzymatic activities like dehydrogenase, protease were significantly higher in hyperthermophilic composting compared to traditional composting (Xiao et al. 2009). The genera involved in carbohydrate and amino acid metabolism remarkably increased during the first 28 days in the HTPRT pile and dramatically decreased at day 42 . However, the sequences related to carbohydrate and 
amino acid metabolism showed a continuous increasing trend in CK. These results are supported by the observations where faster degradation of organic matter recorded in the HTPRT in the active stage of composting process. The results observed imply that the HTPRT pile reached a stabilization period (maturity stage) in advance because biodegradable carbohydrate and amino acids rapidly decreased in the sludge during the thermophilic period (Wu et al. 2017; Wang et al. 2018).

\section{CONCLUSIONS}

1. The authors' results demonstrated that the composting process was remarkably enhanced by hyperthermophilic pretreatment (HTPRT) at $85^{\circ} \mathrm{C}$ for $4 \mathrm{~h}$.

2. The HTPRT decreased bulk density, facilitated the solubilization of complex organic components into small ones, accelerated OM stabilization, and shortened the composting process 18 days.

3. The HTPRT favored $\mathrm{N}$ mineralization and enhanced $\mathrm{N}$ retention.

4. Distinct microbial communities were formed in the thermophilic and maturity phases dominated by thermotolerant Bacilli and Actinomycetales, indicating the bacteria were mainly responsible for the degradation of organic matter. The results of bioinformatics analysis using PICRUSt demonstrated that poultry wastes pretreated with HTPRT were characterized by abundance of genes encoding enzymes contributing to amino acid metabolism, carbohydrate metabolism and lipid metabolism in the active stage of composting.

\section{ACKNOWLEDGEMENTS}

This research was supported by the National Natural Science Foundation of China (Nos. 41701340 and 31700099), the National Key Technology R \& D Program (No. 2016YFD0501401), the Jiangsu Agricultural Science and Technology Innovation Fund (No. CX(18)3016), and the Jiangsu Academy of Agricultural Sciences Research Foundation (No. 027026111631).

\section{REFERENCES CITED}

Benito, M., Masaguer, A., Moliner, A., Arrigo, N., and Palma, R. M. (2003). "Chemical and microbiological parameters for the characterization of the stability and maturity of pruning waste compost," Biol. Fert. Soils 37(3), 184-189. DOI: 10.1007/s00374003-0584-7

Bernal, M. P., Paredes, C., Sanchez-Monedero, M. A., and Cegarra, J. (1998). "Maturity and stability parameters of composts prepared with a wide range of organic wastes," Bioresource Technol. 63(1), 91-99. DOI: 10.1016/S0960-8524(97)00084-9

Cao, Y., Huang, H., Sun., J., Wu, H., Duan, H., Xu, Y., Jin, H., and Chang Z. (2018). "Effect of hyperthermophilic pretreatment on transformation and losses of $\mathrm{C}$ and $\mathrm{N}$ 
during pig manure composting," China Environ. Sci. 38(5), 1792-1800.

DOI:10.19674/j.cnki.issn1000-6923.20180223.003

Cao, Y., Huang, H., Wu, H., Xu, Y., and Chang, Z. (2019). “Optimization of conditions for promotion of humic substance formation during subsequent composting with hythermal pretreatment for pig manure and rice straw," China Environ. Sci. 39(5), 2055-2062. DOI:10.19674/j.cnki.issn1000-6923.2019.0247

China Statistical Yearbook. (2016). China Statistics Press, Beijing, China.

Ding, L., Cheng, J., Qiao, D., Yue, L., Li, Y., Zhou, J., and Cen, K. (2017). “Investigating hydrothermal pretreatment of food waste for two-stage fermentative hydrogen and methane co-production," Bioresource Technol. 241, 491-499. DOI:

10.1016/j.biortech.2017.05.114

Eskicioglu, C., Monlau, F., Barakat, A., Ferrer, I., Kaparaju, P., Trably, E., and Carrère, H. (2017). "Assessment of hydrothermal pretreatment of various lignocellulosic biomass with $\mathrm{CO}_{2}$ catalyst for enhanced methane and hydrogen production," Water Res. 120, 32-42. DOI: 10.1016/j.watres.2017.04.068

Fan, Y. V., Lee, C. Y., Klemes, J. J., Chua, L. S., Sarmidi, M. R., and Leow, C. W. (2017). "Evaluation of effective microorganisms on home scale organic waste composting," J. Environ. Manage 216, 41-48. DOI: 10.1016/j.jenvman.2017.04.019

Gannes, V., Eudoxie, G., and Hickey, W. J. (2013a). "Insights into fungal communities in composts revealed by 454-pyrosequencing: Implications for human health and safety," Front Microbiol. 4, Article 164. DOI: 10.3389/fmicb.2013.00164

Gannes, V., Eudoxie, G., and Hickey, W. J. (2013b). "Prokaryotic successions and diversity in composts as revealed by 454-pyrosequencing," Bioresource Technol. 133, 573-580. DOI: 10.1016/j.biortech.2013.01.138

Jain, M. S., Siddhartha, P., and Kalamdhad, A. S. (2019). "Utilization of biochar as an amendment during lignocellulose waste composting: Impact on composting physics and realization (probability) amongst physical properties," Process Saf. Environ. 121, 229-238. DOI: 10.1016/j.psep.2018.10.031

Jindo, K., Sonoki, T., Matsumoto, K., Canellas, L., Roig, A., and Sanchez-Monedero, M. A. (2016). "Influence on biochar addition on the humic substances of composting manures," Waste Manage. 49, 545-552. DOI: 10.1016/j.wasman.2016.01.007

Jurado, M. M., Suárez-Estrella, F., López, M. J., Vargas-García, M. C., López-González, J. A., and Moreno, J. (2015). "Enhanced turnover of organic matter fractions by microbial stimulation during lignocellulosic waste composting," Bioresource Technol. 186, 15-24. DOI: 10.1016/j.biortech.2015.03.059

Kanazawa, S., Ishikawa, Y., Tomita-Yokotani, K., Hashimoto, H., Kitaya, Y., Yamashita, M., Nagatomo, M., Oshima, T., Wada, H., and Space Agriculture Task Force. (2008). "Space agriculture for habitation on Mars with hyper-thermophilic aerobic composting bacteria," Adv. Space Res. 41(5), 696-700. DOI:

10.1016/j.asr.2007.09.040

Langarica-Fuentes, A., Zafar, U., Heyworth, A., Brown, T., Fox, G., and Robson, R. D. (2014). "Fungal succession in an in-vessel composting system characterized using 454 pyrosequencing," FEMS Microbiol. Ecol. 88(2), 296-308. DOI: 10.1111/15746941.12293

Liao, H. P., Lu, X. M., Rensing, C., Friman, V. P., Geisen, S., Chen, Z., Yu, Z., Wei, Z., Zhou, S. G., and Zhu, Y. G. (2018). "Hyperthermophilic composting accelerates the removal of antibiotic resistance genes and mobile genetic elements in sewage sludge," Environ. Sci. Technol. 52(1), 266-276. DOI: 10.1021/acs.est.7b04483 
Liu, D. Y., Zhang, R. F., Wu, H. S., Xu, D. B., Tang, Z., Yu, G. H., Xu, Z. H., and Shen, Q. R., (2011). "Changes in biochemical and microbiological parameters during the period of rapid composting of dairy manure with rice chaff," Bioresource Technol. 102(19), 9040-9049. DOI: 10.1016/j.biortech.2011.07.052

Liu, H. T., Wang, L. X., and Lei, M. (2019). "Positive impact of biochar amendment on thermal balance during swine manure composting at relatively low ambient temperature," Bioresource Technol. 273, 25-33. DOI: 10.1016/j.biortech.2018.10.033

Liu, N., Zhou, J., Han, L., Ma, S., Sun, X., and Huang, G. (2017). "Role and multi-scale characterization of bamboo biochar during poultry manure aerobic composting," Bioresource Technol. 241, 190-199. DOI: 10.1016/j.biortech.2017.03.144

Lv, B., Xing, M., Yang, J., and Zhang, L. (2015). "Pyrosequencing reveals bacterial community differences in composting and vermicomposting on the stabilization of mixed sewage sludge and cattle dung," Appl. Microbiol. Biot. 99(24), 10703-10712. DOI: $10.1007 / \mathrm{s} 00253-015-6884-7$

Musto, M., Faraone, M., Cellini, F., and Musto, E. (2014). "Changes of DNA quality and meat physicochemical properties in bovine supraspinatus muscle during microwave heating," J. Sci. Food Agri. 94(4), 785-791. DOI: 10.1002/jsfa.6441

Nakhshiniev, B., Biddinika, M. K., Gonzales, H. B., Sumida, H., and Yoshikawa, K. (2014). "Evaluation of hydrothermal treatment in enhancing rice straw compost stability and maturity," Bioresource Technol. 151, 306-313. DOI: 10.1016/j.biortech.2013.10.083

Partanen, P., Hultman, J., Paulin, L., Auvinen, P., and Romantschuk, M. (2010). "Bacterial diversity at different stages of the composting process," BMC Microbiol. 10, 94-103. DOI: 10.1186/1471-2180-10-94

Rice, S. A., and Doty, P. (1957). "The thermal denaturation of desoxyribose nucleic acid," J. Am. Chem. Soc. 79(15), 3937-3947. DOI: 10.1021/ja01572a001

Ryckeboer, J., Mergaert, J., Coosemans, J., Deprins, K., and Swings, J. (2003). "Microbiological aspects of biowaste during composting in a monitored compost bin," J. Appl. Microbiol. 94(1), 127-137. DOI: 10.1046/j.1365-2672.2003.01800.x

Sakalar, E., Abasiyanik, M. F., Bektik, E., and Tayyrov, A. (2012). "Effect of heat processing on DNA quantification of meat species," J. Food Sci. 77(9), 40-44. DOI: 10.1111/j.1750-3841.2012.02853.x

Sánchez-García, M., Alburquerque, J. A., Sánchez-Monedero, M. A., Roig, A., and Cayuela, M. L. (2015). "Biochar accelerates organic matter degradation and enhances $\mathrm{N}$ mineralisation during composting of poultry manure without a relevant impact on gas emissions," Bioresource Technol. 192, 272-279. DOI: 10.1016/j.biortech.2015.05.003

Samaddar, S., Han, G. H., Chauhan, P. S., Chatterjee, P., Jeon, S., and Sa, T. (2019). "Changes in structural and functional responses of bacterial communities under different levels of long-term compost application in paddy soils," J. Microbiol. Biotechnol. 29(2), 292-296. DOI:10.4014/jmb.1811.11018

Steger, K., Jarvis, A., Vasar, T., Romantschuk, M., and Sundh, I. (2007). "Effects of differing temperature management on development of Actinobacteria populations during composting," Res. Microbiol. 158(7), 617-624. DOI:

10.1016/j.resmic.2007.05.006

Steiner, C., Das, K. C., Melear, N., and Lakly, D. (2010). "Reducing nitrogen loss during poultry litter composting using biochar," J. Environ. Qual. 39(4), 1236-1242. DOI: $10.2134 /$ jeq2009.0337 
Tang, J., Wang, M., Zhou, Q., and Nagata, S. (2011). "Improved composting of Undaria pinnatifida seaweed by inoculation with Halomonas and Gracilibacillus sp. isolated from marine environments," Bioresource Technol. 102(3), 2925-2930. DOI: 10.1016/j.biortech.2010.11.064

Tashiro, Y., Tabata, H., Itahara, A., Shimizu, N., Tashiro, K., and Sakai, K. (2016). "Unique hyper-thermal composting process in Kagoshima City forms distinct bacterial community structures," J. Biosci. Bioeng. 122(5), 606-612. DOI: 10.1016/j.jbiosc.2016.04.006

Tortosa, G., Castellano-Hinojosa, A., Correa-Galeote, D., and Bedmar, E. J. (2017). "Evolution of bacterial diversity during two-phase olive mill waste ("alperujo") composting by 16S rRNA gene pyrosequencing," Bioresource Technol. 224, 101-111. DOI: 10.1016/j.biortech.2016.11.098

Wang, K., Mao, H., and Li, X. (2018). "Functional characteristics and influence factors of microbial community in sewage sludge composting with inorganic bulking agent," Bioresource Technol. 249, 527-535. DOI: 10.1016/j.biortech.2017.10.034

Wu, J., Zhao, Y., Zhao, W., Yang, T., Zhang, X., Xie, X., Cui, H., and Wei, Z. (2017). "Effect of precursors combined with bacteria communities on the formation of humic substances during different materials composting," Bioresource Technol. 226, 191199. DOI: 10.1016/j.biortech.2016.12.031

Xi, B., He, X., Dang, Q., Yang, T., Li, M., Wang, X., Li, D., and Tang, J. (2015). "Effect of multi-stage inoculation on the bacterial and fungal community structure during organic municipal solid wastes composting," Bioresource Technol. 196, 399-405. DOI: 10.1016/j.biortech.2015.07.069

Xiao, Y., Zeng, G. M., Yang, Z. H., Shi, W. J., Huang, C., Fan, C. Z., and Xu, Z. Y. (2009). "Continuous thermophilic composting (CTC) for rapid biodegradation and maturation of organic municipal solid waste," Bioresour Technol. 100(20), 48074813. DOI: 10.1016/j.biortech.2009.05.013.

Yamada, T., Miyauchi, K., Ueda, H., Ueda, Y., Sugawara, H., Nakai, Y., and Endo, G. (2007). "Composting cattle dung wastes by using a hyperthermophilic pretreatment process: Characterization by physicochemical and molecular biological analysis," $J$. Biosci. Bioeng. 104(5), 408-415. DOI: 10.1263/jbb.104.408

Yamada, T., Suzuki, A., Ueda, H., Ueda, Y., Miyauchi, K., and Endo, G. (2008).

"Successions of bacterial community in composting cow dung wastes with or without hyperthermophilic pre-treatment," Appl. Microbiol. Biot. 81(4), 771-781. DOI: 10.1007/s00253-008-1736-3

Yu, Z., Tang, J., Liao, H., Liu, X., Zhou, P., Chen, Z., Rensing, C., and Zhou, S. (2018). "The distinctive microbial community improves composting efficiency in a full-scale hyperthermophilic composting plant," Bioresource Technol. 265, 146-154. DOI: 10.1016/j.biortech.2018.06.011

Zhang, L., and Sun, X. (2014). "Changes in physical, chemical, and microbiological properties during the two-stage co-composting of green waste with spent mushroom compost and biochar," Bioresource Technol. 171, 274-284. DOI: 10.1016/j.biortech.2014.08.079

Zhang, J., Chen, G., Sun, H., Zhou, S., and Zou, G. (2016a). "Straw biochar hastens organic matter degradation and produces nutrient-rich compost," Bioresource Technol. 200, 876-883. DOI: 10.1016/j.biortech.2015.11.016

Zhang, L., Zhang, H., Wang, Z., Chen, G., and Wang, L. (2016b). "Dynamic changes of the dominant functioning microbial community in the compost of a $90-\mathrm{m} 3$ aerobic 
solid state fermentor revealed by integrated meta-omics," Bioresource Technol. 203, 1-10. DOI: 10.1016/j.biortech.2015.12.040

Zhao, Y., Zhao, Y., Zhang, Z., Wei, Y., Wang, H., Lu, Q., Li, Y., and Wei, Z. (2017). "Effect of thermo-tolerant actinomycetes inoculation on cellulose degradation and the formation of humic substances during composting," Waste Manage. 68, 64-73. DOI: 10.1016/j.wasman.2017.06.022

Zhao, Y., Zhao, Y., Zhang, Z., Wei, Y., Wang, H., Lu, Q., Li, Y., and Wei, Z. (2018). "Influence of inoculating white-rot fungi on organic matter transformations and mobility of heavy metals in sewage sludge based composting," J. Hazard. Mater. 344, 163-168. DOI: 10.1016/j.jhazmat.2017.10.017

Zhou, C., Liu, Z., Huang, Z., Dong, M., Yu, X., and Ning, P. (2015). “A new strategy for composting dairy manure with rice straw: Addition of different inocula at three stages of composting," Waste Manage. 40, 38-43. DOI: 10.1016/j.wasman.2015.03.016

Zucconi, F., Pera, A., Forte, M., and De Bertoldi, M. (1981). "Evaluating toxicity of immature compost," Biocycle 22(2), 54-57.

Article submitted: March 10, 2019; Peer review completed: June 16, 2019; Revised version received and accepted: June 28, 2019; Published: July 5, 2019.

DOI: 10.15376/biores. 14.3.6747-6766 